\title{
PROTECTION IN RETAIL INVESTORS DISADVANTED BY \\ FAKE TRANSACTION PRACTICE (CORNERING THE
}

\author{
MARKET)
}

\author{
DESTU ARGIYANTO \\ Supervising Society at Purwokerto Penitentiary \\ Pasukan Pelajar Imam Street No. 7 Purwokerto \\ mahapatihdestarata@gmail.com
}

\begin{abstract}
The practice of fake transaction is a stock trading practice that incurs many losses, especially for retail investors who basically do not control the market in majority on the floor of the stock. This practice may threaten the liquidity and credibility of capital market activities in Indonesia. Pseudo transaction is one of the crimes prohibited in Capital Market Law which fall into the category of market manipulation. In simple terms, market manipulation is an activity undertaken by a person either directly or indirectly creating a false or misleading image of a trading activity, market situation, or price of Securities at a Stock Exchange or giving a statement, or an improper, or misleading statement so that the price of the securities in bursa affected. Provisions on market manipulation are provided in Articles 91, 92 and 93 of Law Number 8 of 1995 concerning the Capital Market.
\end{abstract}

Keywords : Concerning the market, Ritel Investors, Protection

\section{INTRODUCTION}

The capital markets bring together the owner of funds with the user of funds for medium term investment purposes. Both parties do the buying and selling of capital in the form of securities. The owner of the fund handed over a number of funds and the recipient of the fund (open company) submitted proof of ownership in the form of securities.

The Financial Services Authority (OJK) as the institution with the highest authority in the capital market is expected to avoid Indonesia from economic difficulties. One example of OJK authority in supervision in the field of capital market is OJK can take action that is preventive and repressive in order to smooth 
the implementation of capital market in Indonesia. Law Number 21 Year 2011 also authorizes OJK as an investigator for capital market actors who commit violations and criminal actions and may impose sanctions as stipulated in law.

Investments in capital markets especially stocks have high return but also high risk. Due to the existence of such high risk, the law is required to provide security and security to share investors in transacting in the world of capital markets. Looking at the facts so far, the protection provided by law has not fully guaranteed the security of investors in investing in the capital market, particularly the protection of the fake-transaction practices carried out by a group or part of people who can certainly harm retail investors.

Fake Transaction or known by the term fried stock (cornering the market) is one of the actions that fall into the category of prohibited market manipulation in Act No. 8 of $1995 .{ }^{1}$ Transactions of this type are usually done by bandar or manipulator who have more funds which in principle the dealers will conduct transactions on the floor of the exchange with various models that can attract other investors into the stock transactions. In practice the process of raising the stock price can be done by cooperating among securities firms in this case acting as a broker where the securities companies in cooperation with the dealer or manipulator to buy stocks fried at a certain price, then prices are made continuously rising so that the market reacts with increasing demand for these shares. Then at a given price level, the manipulator will sell or release all shares held and done on a large scale. If the company has no good foundation or fundamentals then the stock price that has been fried will drop significantly.

So far, the role of the Financial Services Authority (OJK) in providing protection to investors is considered quite lacking, this is evidenced by the handling of cases of fake transactions or fried stocks against the manipulators who have not been sentenced to the maximum. The role of the Financial Services

\footnotetext{
${ }^{1}$ Act No 91 UUPM: "Any party engaging in Capital Market activities is prohibited from taking action, directly or indirectly, in order to create a false or misleading picture of trading activities, market conditions or securities prices on the Stock Exchange."
} 
Authority $(\mathrm{OJK})$ is needed to protect the interests of investors in order to create a regular, fair and efficient capital market.

\section{RESEARCH METHODS}

The type of research used is qualitative research. The research approach used is empirical juridical or non-doctrinal research (socio-legal research). Research character used descriptive analytical. The descriptive analytical of the descriptive research will provide as accurate data as possible about the role of the Financial Services Authority (OJK) as well as the factors that hinder it in providing protection to related retail investors who are harmed as a result of the fake-transactional practices in stock trading on the exchange.

The types and sources of data that will be used are primary and secondary data. The data collections techniques used were interviews, observation and documentation. Technique examination of data validity in this research use technique triangulation. Triangulation technique is a technique of checking the validity of data that utilizes something other than that data for checking purposes or as a comparison against that data. ${ }^{2}$ Triangulation with sources means comparing and checking both the degree of confidence of information acquired through time and tools that are in the way of a researcher's qualified method.

Techniques of data analysis in research are the most important thing for the data that has been collected can be accounted and can generate answers from the problems studied. Researchers use qualitative analysis techniques with interactive models owned by Miles and Huberman, namely component data reduction and data presentation performed together with data collection, and then after the data collected then the three components interact and if the conclusion is felt less, then there needs to be verification and re-research by collecting data field.

\section{RESULTS AND DISCUSSION}

The OJK Role In Providing Legal Protection To Retail Investor Related Losses Due to Fake Transaction (Cornering The Market)

\footnotetext{
${ }^{2}$ Moeleong, op. cit. page 178.
} 
Financial Services Authority (OJK) in performing the task of regulating and supervising the capital market sector has an organizational structure that works in accordance with their respective duties and functions. The TLE Directorate of its therapeutic side is conducting monitoring of stock transactions of listed companies traded on the exchange; we have our own monitoring system just like the stock exchange. In case of any indication of violation of Articles 91 and 92 of the Capital Market Law, we shall enter into a review stage involving external data from (Exchange Members, IDX and KSEI). We are tasked to find the parties who are involved in the trade, if it has found at least 2 kinds of strong indications we bestowed to DPKM. The Directorate of Securities Transaction Supervision is a part of surveillance or supervision of trading transactions on the stock for either type of equity, bonds or derivatives. This means that OJK also has its own monitoring system as what is done in Indonesia Stock Exchange. If there is any indication of any violation of the capital market, particularly violation of fake transactions (Article 91 UUPM) and Fried Stock/Cornering (Article 92 UUPM), the surveillance will monitor the shares for several periods, which will then progress to the review stage. The review stage serves to find the parties to anyone involved in the trade, involving data from Members of the Securities Exchange, Indonesia Stock Exchange, and Indonesia Central Securities Depository.

The Directorate of Securities Transaction coordinates with the Indonesian Securities Exchange in performing its duties and functions if it finds any suspicious transactions or leads to violations of the capital market, particularly for violations of Articles 91, 92 and 95 UUPM. The deadline set for monitoring and reviewing the Directorate of Securities Transaction will take 1-3 months. In conducting supervision of Directorate Surveillance will make report in the form of Technical Inspection Result Report (LHP) which will later be submitted to DPKM. Processed stages of review we can allow directly delegated to DPKM but not in the form of LHP but using the Office Notes Abundant if we already have strong evidence of early indications of violations. The Technical LHP contains the results of an examination of an existing report on the request of the result of the 
examination result while the Office Note only describes the information supported by strong data there is an early indication of violation.

Furthermore, the OJK stages in handling capital market violation cases after the Directorate of Transaction and Securities Institution Supervision completed the Technical Review Result Report (LHP) is delegated to the Directorate of Capital Market Inspection (DPKM).

The Directorate of Capital Market Inspection in performing its duties and functions shall obtain an abundance of the Indonesia Stock Exchange and the Directorate of Transactions and the OJK Securities Institution in the form of reports of indications of violations of the capital market. OJK does not provide standardization related to reports from Indonesia Stock Exchange, BEI delegate to OJK if found an indication of violation of capital market conducted by investor. This is because the authority of the stock is only at the level of examination of the Securities Exchange Member.

The Indonesia Stock Exchange has the authority to audit the Securities Exchange Member. The inspection conducted by BEI is a series to search, collect and process data and other information conducted by the Exchange to prove or indicate whether or not there is a violation of stock exchange rules and regulations in the field of capital market. IDX can not conduct check up to investor level, therefore if there is any indication of violation by investor, BEI transferred to Directorate of Capital Market OJK Inspection.

The Directorate of Capital Market Inspection (DPKM) of OJK has a period of time to complete a check of the violation in the capital market for a maximum of 12 (twelve) months. Outcome/output of the Directorate of Capital Market Inspection is recommendation, whether from examination of the violation case will go into investigation stage or will be subject to administrative sanction. Furthermore, after the Directorate of Capital Market Inspection issues recommendation result, if the case which has been examined recommend to be subject to administrative sanction it will be transferred to Directorate of Sanction and Objection of Capital Market (DSKP). 
Directorate of OJK Sanctions and Capital Market Objection (DSKP) in performing its duties and functions to impose administrative sanctions to parties that violate the provisions of laws and regulations in the field of capital market is based on the provision of Government Regulation (PP) No 45 Year 1995 Act 6165. DPSK OJK has a deadline for determining administrative sanctions to parties proven to violate laws and regulations in the capital market must be completed within 3 (three) months. If the Directorate of Capital Market Inspection OJK recommends a case of capital market violation to enter the investigation stage it will be delegated to the Directorate of Investigation OJK. The Directorate of Inquiry follows up the examination process of the Capital Market, Banking and IKNB, this is because each sector of OJK has its own section of examination. Terms of a violation in the field of capital market to be able to enter the stage of investigation must have at least 2 evidences, as specified in the Indonesian Criminal Procedure Code. If there is a foreign party who becomes one of the perpetrators of violation of the laws and regulations in the field of capital market OJK step is to cooperate with the supervisory authority of Financial Services Institutions in other countries.

OJK has been a signatory of the International Organization of Securities Commissions (IOSCO) of Multilateral Memorandum of Understanding (MMoU) since January 2014. It is an acknowledgment from IOSCO as Global Standards Setter for the world capital market industry that the Indonesian capital market regulation has equaled the members Other IOSCO in the context of law enforcement. One of the benefits obtained by OJK as a signatory of the MMoU is the recognition of OJK's right to request information from the state capital market authorities in the event of an indication of the involvement of an individual or a foreign business entity in violation or crime in the Indonesian capital market.

Consumers if they feel disadvantaged related to transactions activities in the capital market can report to OJK through Education and Consumer Protection. Violations perpetrated by market actors, especially those related to violations of fake or cornering transactions as regulated in Articles 91 and 92 of the Capital Market Law may cause injustice to other market participants. 


\section{Barriers And Efforts That Can Be Provided By Stock Authorities And Financial Services Authorities (OJK) In Providing Legal Protection To Retail Investors Related Losses Due to Fake Transactions (Cornering The Market)}

Indonesian Stock Exchange has barriers to the system used in an effort to maintain market liquidity in capital market violations. Further, constraints or obstacles experienced by the Directorate of Capital Market Inspection (DPKM) OJK related to the examination of the parties that are in violation of the provisions of capital market laws and regulations are those in the region that can not fulfill the OJK call due to constrained transportation cost problems. OJK Oversight of the Capital Market sector is still concentrated in Jakarta, so it is this that makes each party that is indicated to be a violation must come to Jakarta to fulfill OJK's call. Efforts made by the OJK to overcome the obstacles of parties indicated by the violation of the capital market are to go directly to the parties. The next obstacle found in the inspection process is a fake transactions or cornering conducted by foreign parties or investors, where OJK has difficulty to detect transactions conducted by foreign investors. Efforts are made to overcome this, the examiner to call the securities company that resides in Indonesia to convey to overseas branches that OJK requires data of foreign investors.

The next obstacle experienced by the OJK capital market examiner is the difference of opinion between the OJK Investigator sections with the Investigator; this is because the OJK's invertigator comes from the Police. Efforts made by OJK Examiners to overcome the above are to convince the OJK Investigator by providing sufficient accurate evidences.

\section{CONCLUSION}

Indonesia Stock Exchange in indicating a violation of fake transaction or cornering make preventive efforts to maintain liquidity of capital market trading in Indonesia to stay orderly, reasonable and efficient. These efforts include the issuance of Unusual Market Activity (UMA) as well as the suspension of securities trading activities (Suspension). In addition to preventive efforts, BEI will also conduct repressive efforts in the form of inspection and imposition of 
sanctions against the Securities Exchange Members involved in violation of capital market laws and regulations.

The role of the Financial Services Authority (OJK) in providing protection to investors is done by repressive efforts against all parties suspected of violating Article 91 (fake-transactions) and Article 92 (cornering) of UUPM. Such repressive efforts include monitoring and reviewing of unusual stock transactions, examination of indications of violations of capital market regulations, administrative sanctions, and investigations in the event of a criminal offense in violation of transactions as well as cornering.

Obstacles and efforts faced by BEI and OJK in providing legal protection to investors include: (1) the obstacle faced by BEI as a provider of securities trading is a supervisory system that has not been able to stop automatically trading unfair trading activities. Efforts made by IDX are to apply price restrictions and auto rejection as well as suspension of shares that are indicated unnatural. (2) Obstacles faced by OJK: First, the parties examined can not fulfill the call on the grounds due to transportation costs. Efforts made are OJK Examiner go directly to the parties concerned. Second, OJK can not detect transactions conducted by foreign investors individually. The efforts made are the OJK Examiner notifying the Members of the Joint Venture Exchange domiciled in Indonesia to request the data of foreign investors conducting transactions to the branch of a Joint Stock Exchange Member domiciled in the country of residence of the foreign investor. Third, the differences of opinion between OJK Examiner and OJK Investigator in determining the elements of fake transactions violation. Efforts made by the OJK Examiner are clearly convinced to the OJK Investigator by providing sufficiently accurate evidences that has been found at the time of examination.

\section{SUGGESTION}

Given that the system used by the Exchange Members is very diverse and has not been standardized, PT Bursa Efek Indonesia as the provider of securities trading is expected to standardize the remote trading or online trading system used by the Exchange Members. This is done so that the overall trading of securities 
conducted by the Exchange Members produces accurate data output and minimizes the misuse of the system by the Exchange Members.

OJK has not provided a preventive legal protection against violation of fake transaction as well as cornering as regulated in Article 91 and Article 92 of Capital Market Law. Therefore, OJK is expected to make an implementing regulation relating to market manipulation, especially regulations for fake transactions and cornering.

Related to the difference of opinion between OJK Inspector and OJK Investigator (Police of RI and PNS of Ministry of Finance) in determining the element of violation in Capital Market area, need enough effort of coordination between OJK institutions and supported enough by Capital Market knowledge adequate.

\section{BIBLIOGRAPHY}

Fathul AH, Lucky. 2016. OJK Consumer Service Press Release Apply Trackable and Traceable Facilities. Jakarta: OJK

Fuady, Munir. 1996. Modern Capital Market (Legal Review). Bandung: Citra Aditya Bakti

Halim, Abdul. 2005. Investment Analysis. Jakarta: Salemba Four

Hartanto, Arif. et. al. 2015. Awaiting The New Concept of Derivative Trade Pension Fund $64^{\text {th }}$ Edition Magazine. Jakarta: PT Jagatmedia \& Business. p. 12.

Hazen, Thomas Lee. 1990. The Law of Securities Regulation. St. Paul Minnesola: West Publishing Co.

Husnan, Suad. 1993. The Basics of Portopolio Theory and Analysis of Securities. Yogyakarta: UPP-AMP YKPN

Pramono, Nindyo. 2013. Law of PT Go Public and Capital Market. Yogyakarta: ANDI

Rahardjo, Budi. 2009. Jelly Investments in Ala Warren Buffet Stock: A ProfitTaking Strategy in the Crisis. Yogyakarta: ANDI 
Shook RJ and Shook, Robert L. The Wall Street Direct Dictionary, p. 234

Usman, Marzuki. et. al . 1990. ABC Capital Market Indonesia . Jakarta: LPPI and ISEI

\section{Scientific journals:}

Balfas, Hamud M. 1998. Criminal Acts of the Capital Market and Trade Supervision at the Exchange. Journal of Law and Development Edition January-June 1998 p. 15.

Lestari, Hesty D. 2012. Financial Services Authority: The New System In The Regulation and Supervision of Financial Services Sector. Journal of Legal Dynamics Vol. 12 No. 3 of 2012, p. 558.

Safitri, Indra. 2008. The Role of Capital Market Law in the Development of Indonesia's Economy. Indonesian Legislation Journal Vol. 5 No. 2 June 2008, p. 6. 